\title{
Daniel Ziarkowski
}

Oddział Monitoringu Naukowego, Biblioteka Główna Uniwersytetu Szczecińskiego

E-MAIL: daniel.ziarkowski@usz.edu.pl

\section{Socjologiczne i psychologiczne aspekty funkcjonowania zespołów rockowych}

\begin{abstract}
STRESZCZENIE
Powiedzieć, że zespół muzyczny to grupa wykonawców wspólnie grających muzykę to nie powiedzieć nic. Tak jak poszukiwacze skarbów, gdzie jeden zna miejsce, drugi wie jak założyć szalunki, a trzeci umie ocenić i odróżnić minerały od kamieni szlachetnych, tak w grupie muzycznej każdy jest inny i niezbędny zarazem. Od ich wzajemnych relacji, uczuć, myśli, słów i możliwości zależy, czy skarb zostanie odnaleziony, jakie ofiary poniosą po drodze i czy ich własne ego nie przerośnie ich samych. Jeżeli wszystko pójdzie dobrze, to złota muzyka pozostanie po nich na wiele lat, a może nawet pójść w pokolenia. Tylko pytanie, jak nie zerwać więzi? Jak pozostać sobą? Jak się nie zagubić i jak odnaleźć...?
\end{abstract}

sŁowA KLUCzowe: zespół rockowy, relacje interpersonalne, psychologizm, komunikacja społeczna, osobowość, grupa

Zjawisko funkcjonowania zespołu rockowego, do tej pory zupełnie niesłusznie bagatelizowane i pomijane w literaturze przedmiotu, zasługuje na szersze omówienie i zanalizowanie. Twór to wyjątkowy, bo stanowiący zamkniętą grupę społeczną z całym bagażem jej psychologizmu, relacji personalnych, napięć, idei, emocji i czyste źródło informacji o człowieku twórczym i zaplątanym w sieć wzajemnych zależności. W kontekście muzyki rockowej wydaje się być jakby niezauważony zarówno przez domorosłych badaczy, jak i poważnych naukowców. Być może wynika to z faktu nieznajomości problemu i braku empirii w tym temacie, wiadomo bowiem powszechnie, że badacz biorący udział w eksperymencie zatraca obiektywizm sytuacji, ale jako jeden z uczestników jest dostarczycielem uczuć i przeżyć, które z kolei są obce i zawsze będę, zwykłemu obserwatorowi. Tym większa wartość słów piszącego, który niejednokrotnie uczestniczył nie tylko w tej zamkniętej grupie społecznej zwanej zespołem rockowym, ale i w samym akcie tworzenia takiej grupy. 


\section{Powołanie}

Już sam proces inicjujący warty jest odnotowania. Nierzadko bowiem wygląda to jak spisek uknuty przeciwko komuś lub czemuś, choć zazwyczaj ma charakter pro, a nie kontra. Protwórczy, prowyzwalający, proekspiacyjny, pro-humanistyczny wreszcie. Bo jak inaczej nazwać obcowanie ze sztuką i chęcią jej współtworzenia? Zwierzętom obca jest sztuka, jest dla nich abstrakcją, której nie da się skonsumować, a człowiek przy wszystkich swoich zapędach destrukcyjnych zdaje się być istotą wręcz powołaną do kreowania nowych wartości, rzeczy i zjawisk. Jednym z tych zjawisk jest zespół rockowy. Tak więc, powołanie takiej chimery do życia opiera się na idei, planie i realizacji tegoż. Samowystarczalny solista nie jest zespołem, więc to do realizacji takiego planu potrzebna jest grupa osób, która zarażona ideą staje się jej niezbywalną częścią. Ktoś powie - „No tak, ale cóż w tym wyjątkowego? Przecież na idei i planie zasadza się każda działalność zespołowa, czy to jest wejście na K-2, czy zorganizowanie drużyny piłkarskiej, czy założenie partii politycznej. Obojętnie. Wszystkie działania kolektywne muszą mieć taki sam początek”. To prawda. Jednak powołanie zespołu muzycznego wymaga czegoś więcej. Tutaj niezbędny jest duch twórczy, samo zaś obcowanie z muzyką wewnątrz tej grupy nadaje jej niepowtarzalny i oryginalny charakter. Spowija jej uczestników czymś niewidzialnym, tak jak niewidzialna jest sama muzyka. Polihymnia przesiadująca w każdej salce prób zespołów na całym świecie splata członków zespołu niewidzialną nicią mistycyzmu, bo czymże jest tworzenie muzyki, jeśli nie pukaniem do świątyni Muz? Czymże jest, jeśli nie wychylaniem głowy ponad ziemski padół i wypatrywaniem horyzontów poza granicą ludzkiej bytności, codzienności, by nie powiedzieć - szarości egzystencji...? Penetrowanie nowych obszarów ludzkiej wrażliwości, ciągłe poszukiwania i chęć oderwania się od ziemi, lot ku nieznanym krainom, oceanom, gwiazdom - to właśnie jest sztuka. Kosmos kreacji, a więc szamaństwo w krystalicznej postaci. Rzecz jasna, nie każda muzyka staje się taką kreacją, nie każde wykonanie. Muzyka z nurtu disco polo z pewnością należy do tej kategorii - jej prymitywizm i obskurantyzm ściąga wręcz ducha twórczości na ziemię, miast dodawać mu skrzydeł. Dlaczego pięciolatkowi śpiewa się piosenkę „Wlazł kotek na płotek”, a nie np. psalmy ludźmierskie? Ktoś mądry napisał tę pioseneczkę dla dzieci, bo wiedział, że umysł pięciolatka nie jest w stanie zarejestrować, ocenić i docenić złożonych linii melodycznych. $\mathrm{Na}$ takim samym poziomie rozwoju są miłośnicy i twórcy muzyki disco polo. Podobają im się proste, nieskomplikowane melodie, bo tylko takie są w stanie zapamiętać i zrozumieć. Tak samo wyglądała muzyka prymitywna, pierwsza muzyka tworzona przez pradawnych ludzi. To było stukanie patyka 
o patyk, w tym samym monotonnym rytmie, a jak wiadomo, powtarzalność tych samych wykonywanych czynności wprowadza człowieka w trans. $\mathrm{Na}$ tej samej zasadzie oparta jest powtarzalność modlitw różańcowych czy śpiewanie mantr, ale to oczywiście już inne zagadnienie wychodzące poza ramy tego skromnego eseju. Głupkowatość melodii, rytmów i słów piosenek discopolowych uwłacza każdemu poważnemu odbiorcy muzyki i cofa ludzkość w rozwoju do pierwszych w historii świata muzykantów o umyśle pięciolatka.

Rozwój muzyki miał swoje apogeum wczasach baroku i renesansu, w czasach polifonii i matematycznej wręcz złożoności harmonii i dźwięków, w której każdy następny dźwięk był konsekwencją poprzedniego i jego naturalną koniecznością i oczywistością. Ale i muzyka współczesna, rozrywkowa, rockowa dostarczyła odbiorcom wiele nowych pól do przekopania i dróg do przejścia. Zespół The Beatles wspiął się na sam szczyt możliwości kompozytorskich w muzyce rockowej. Jakież tam bogactwo melodii, harmonii, rytmów, temp! Zupełnie inaczej niż w muzyce disco polo, w której tempo każdej piosenki jest takie samo - $130 \mathrm{bpm}$. Oni nie znają innych. Często słyszy się, że przecież nikogo ci ludzie nie okradają, zarabiają uczciwie. Otóż nie! Okradają słuchaczy z przeczulenia lub inaczej - zabijają go w nich na rzecz tych kilku uderzeń patykiem o patyk. Są złodziejami ludzkiej wrażliwości, tej wrażliwości, która przy odpowiednim przekierowaniu mogłaby zachwycać się muzyką Bacha, Chopina, folkloru andyjskiego, pieśni religijnych, ale nie - oni porywają ją i roztapiają niczym złote precjoza na płynny, pierwotny bezkształt, z którego powstały. To grabież zuchwała i obrzydliwa. Dlatego musimy wyłączyć zespoły tego typu z toku naszych rozważań. Tam nie ma misterium. Tam słychać tylko jak pęcznieje trzos.

\section{Lider czy demokracja?}

Istnieją dwie szkoły funkcjonowania zespołu rockowego. Albo zarządza nim lider albo wszyscy, czyli nikt. Zazwyczaj impuls założenia zespołu idzie od tego, kto ma jakieś pomysły muzyczne, tzw. dar tworzenia. W ślad za tym, co nierzadko jest zwyczajną koleją rzeczy, idzie wizja artystyczna, brzmieniowa, stylistyczna i każda inna. Lider wie, w którym kierunku trzeba się udać, żeby było dobrze. W internecie można znaleźć głos komentujący działalność zespołu Republika: „Ciechowski to był gość. Reszta to gnojki wyciągnięte przez niego na scenę". Komentarz mocny i z pewnością krzywdzący, jednak prawdziwy, jeśli zastosujemy dialektyczne myślenie. Tak właśnie się zdarza w przypadku zespołów z silnym, osobliwym liderem. Przysłania on swoim talentem pozostałych członków zespołu na tyle intensywnie, że nie pozostaje im nic innego jak tylko grzać się w słońcu jego geniuszu, ciesząc się, że to 
właśnie ich wódz wybrał na swoich wspólników w realizacji dzieła. I rzeczywiście, aczkolwiek bez tych pozostałych, pozostających w cieniu, lider nie mógłby zaistnieć. Zespół w tym przypadku jest tylko lektyką wnoszącą faraona w tłum, tylko i aż, bo sama lektyka by się nie wniosła, faraon nie ma takich możliwości sprawczych. Często o tym, że faktycznie, byli oni tylko wyrobnikami dowiadujemy się z dalszych poczynań, już indywidualnych, członków grupy. Zdarza się tak niejednokrotnie po rozpadzie zespołu, śmierci lidera. Wyglądają oni wówczas jak stado bezpańskich psów pozostawionych samym sobie i niewiedzących co ze sobą zrobić. Zagubionych. Błąkają się zwykle po bezdrożach muzyki, zasilając jakieś przygodne sfory, bezładne i bez wyrazu, sami gasnąc z czasem i wtapiając się w tło. Wtedy przekonujemy się jako odbiorcy, ale i do nich samych dociera w końcu ta prawda, że ów lider znał ich możliwości i potrafił je wykorzystać do maksimum. Idealnie uzbroił każdego z nich we właściwy oręż i znalazł im właściwe miejsce w szeregu. $\mathrm{Na}$ tym też polega siła lidera i moc jego wizjonerstwa. Celne przewidywania i umiejętność osadzenia muzyka w odpowiednim miejscu znamionuje prawdziwego przywódcę. On musi być jak reżyser w spektaklu lub jak Bóg we wszechświecie - żeby się go nie widziało nigdzie, ale czuło wszędzie.

Bywa, że w grupach muzycznych, a zwłaszcza w zespołach rockowych, gdzie natura muzyków i ich charaktery są bardziej drapieżne niż np. u muzyków w kwintecie smyczkowym, powstaje opozycja w stosunku do lidera. Czasem na tyle silna, że antagonista zdoła przeciągnąć na swoją stronę pozostałych członków zespołu. Działanie takie, a nawet już jego początki na ogół nie wróżą niczego dobrego. Dzieje się tak zwykle po jakichś niepowodzeniach, przy nagłej lub stopniowej zmianie gustów muzycznych i upodobań któregoś z członków pozostającego pod wrażeniem obejrzanego koncertu, usłyszanej płyty albo w przypadku odczuwalnej tyranii lidera. Jednak do tego zagadnienia dojdziemy w późniejszych rozważaniach opisujących psychologizm zachowań interpersonalnych w zamkniętej grupie społecznej.

Ciekawym przypadkiem braku ewidentnego lidera jest wspomniany już wcześniej zespół The Beatles. Właściwie na dobrą sprawę, przynajmniej w początkowej fazie istnienia zespołu mógł nim być perkusista Ringo Starr. Kiedy dołączył do Bitelsów był już znanym muzykiem zdobywającego coraz większą rzeszę fanów zespołu The Rory Storm and Hurricanes i jawił się on jako najbardziej doświadczony muzyk wśród nieznanych nikomu Bitelsów. Poza tym, był też najstarszy, co w przypadku nastolatków czy dwudziestolatków ma niebagatelne znaczenie. Te różnice z wiekiem zanikają, ale między dziewiętnastolatkiem a np. dwudziestotrzylatkiem jest totalna przepaść. Ringo był też rozpoznawalny - miał tak zwany styl i odpowiedni image 
- nosił sygnety na palcach i był właścicielem brody co na przełomie lat 50. i 60. nie było takie oczywiste wśród młodzieży, a raczej odbierano to jako ekstrawagancję. Skronie przyprószone wczesną siwizną nadawały mu nobliwego wyrazu, tak więc z pewnością wyróżniał się spośród innych młodych ludzi i muzyków tamtego okresu. Ringo nie miał jednak zapędów przodowniczych. Szybko więc lukę tę wypełnił John Lennon, ale bardziej był on postrzegany jako lider przez fanów i ludzi z zewnątrz niż to wyglądało w rzeczywistości. Generalnie w okresie istnienia zespołu dzieli się liderowanie w nim na dwa etapy - w latach 1962-1966 był nim Lennon, zaś lata 1967-1970 to ewidentne szefostwo Paula McCartneya. Jakkolwiek by to jednak nie wyglądało, sami członkowie grupy mówili o demokracji w zespole, w którym przechodził każdy dobry pomysł, niezależnie od tego kto był jego autorem. Stosunek głosów 3:1 decydował o wszystkim. Jeszcze inna teoria głosi, że w Bitelsach było dwóch liderów, co oczywiście jest logicznym nonsensem, w każdym razie przy takim nagromadzeniu talentów w jednym zespole demokracja zdaje się być jedynym słusznym rozwiązaniem.

Niejednokrotnie jako liderów postrzega się wokalistów, tych stojących na przodzie, najbardziej widocznych i słyszalnych. Tak jednak nie jest w wielu przypadkach. Liderem w zespole The Who był gitarzysta Pete Townshend, a nie wokalista Roger Daltrey, a we wczesnej działalności The Rolling Stones zdecydowanie prym wodził Brian Jones, a nie Mick Jagger. Na rodzimym rynku również można znaleźć podobne sytuacje, chociażby w przypadku zespołu Lady Pank, gdzie chyba każdy wskazałby jako lidera Jana Borysewicza, a nie wokalistę Janusza Panasewicza, zaś w starym składzie Perfectu - gitarzystę Zbigniewa Hołdysa, a nie Grzegorza Markowskiego. Z pewnością wynikało to i wynika $\mathrm{z}$ charakterystycznego brzmienia instrumentów wymienionych gitarzystów, ale też ich możliwości kompozytorskich. Nadmienić również należy wpływ ich osobowości na resztę grupy. Widać wyraźnie różnicę między tym, który jest tylko „twarzą” zespołu, a tym, który rzeczywiście mu przewodzi.

\section{Za zamkniętymi drzwiami}

Z socjologicznego punktu widzenia zespół muzyczny jest zjawiskiem niezwykłym. Nosi wszelkie znamiona rodziny, jednak z prostych przyczyn braku pokrewieństwa rodziną nie jest, pomimo nazw sugerujących, że jest inaczej, np. Dikanda (z języka jednego z plemion afrykańskich znaczy rodzina) czy brytyjski zespół rockowy Family ( $\mathrm{z}$ ang. rodzina). Z drugiej jednak strony, kiedy słyszy się historię zespołu Czerwone Gitary, w której to zespół odnotował w jednym roku 360 koncertów, to nie trzeba być geniuszem matematycz- 
nym, żeby skonstatować, iż zespół więcej w tym roku przebywał ze sobą niż z rzeczywistą rodziną. Składają się nań wspólne posiłki, spanie w tych samych pokojach, przejazdy, a więc przebywanie ze sobą non-stop przez wiele, wiele godzin. Jednak nie potrzeba, aż takiego ekstremum, żeby poczuć i zrozumieć więź emocjonalną z pozostałymi członkami zespołu. Samo przebywanie na próbach spaja i łączy w niezwykły sposób, bo chociaż to nie jest rodzina, to nie jest to także zwyczajna grupa współpracowników jak w życiu zawodowym, gdzie celem są pieniądze, pensja, wynagrodzenie, a nie wspólne dzieło. I dotyczy to nie tylko tych znanych i wielkich artystów, którzy notabene prób często-gęsto już nie potrzebują i nie robią, ale zwłaszcza amatorskich grup rockowych. Niejeden nie-muzyk chciałby pobyć trochę na takiej próbie, od kuchni zobaczyć jak to się robi, jak przygotowuje się takie danie muzyczne, jak wygląda proces twórczy. Jest on często zresztą powtarzalny, ale charakterystyczny, w nim bowiem objawia się cała esencja. Na ogół towarzyszy temu procesowi nadmiar emocji i osobistych wynurzeń. Bo oto perkusista nie chce grać tak jak sugeruje mu kompozytor utworu, a gitarzysta nagle stwierdza, że tekst nowej piosenki jest denny. „To napisz lepszy” - odpowiada mu poirytowany autor i już o krok od awantury. Grzegorz Ciechowski zazwyczaj nie miał problemów ze „sprzedaniem” swoich pomysłów zespołowi, ale kiedy ktoś na próbie stwierdził, że numer Klatka jest podobny do motywu muzycznego Różowej Pantery to ponoć już do końca dnia nie odzywał się do nikogo, urażony tą uwagą. Kiedy zaś kompani ignorowali uwagi Tomka Lipińskiego co do aranżacji piosenki, ten z kolei wybiegał trzaskając drzwiami wykrzykując, że odchodzi z zespołu, po czym następnego dnia już jak gdyby nigdy nic spokojnie dalej omawiał przerwany dzień wcześniej wątek. Znane są autorowi tego eseju jednak bardziej drastyczne przypadki, kiedy perkusista wyrzuca przez okno gitarę stwierdzając, że skoro gitarzysta nie umie grać, to po co mu ona. Ten w odwecie dziurawi bębny i tym miłym akcentem kończy się próba tego dnia. Innym razem perkusista innego zespołu po długiej, zaciętej kłótni z basistą, który nie mógł wyczuć synkop granych stopą powtarzając, że są grane nierówno, upraszcza nagle rytm oznajmiając przy tym na cały głos: „Uwaga, gram wersję dla upośledzonych umysłowo!”. Znane są także przypadki zapędów despotycznych liderów rozwieszających kartki na ścianie sali prób z warunkami, jakie od tej chwili mają zapanować i zasadami, do których mają zastosować się członkowie zespołu. Kwitowane jako 95 tez Lutra stawały się zazwyczaj obiektem drwin i szybko doprowadzały do rozpadu grupy. Bob Marley był także autorem słynnej zasady: „Na próbach nie wolno się śmiać". Prawdopodobnie wynikało to $\mathrm{z}$ faktu swobodnego palenia marihuany w trakcie grania, która jak wiadomo rozwesela, więc ni stąd ni 
zowąd naraz wszyscy zaczynali się śmiać zamiast pracować nad utworem. Marley - wielki miłośnik i orędownik królewskiego ziela, rzecz jasna, nie mógł zakazać jego palenia, więc zakazał tylko jakiejś pochodnej tego palenia, na co i tak nie mógł mieć ostatecznie wpływu. Ideałem jest, kiedy zespół tworzą koledzy z jednego podwórka, którzy słuchają tych samych płyt, tak samo się ubierają, myślą i mówią w podobny sposób. Taki zespół już na starcie ma przewagę nad innymi, ponieważ cechy charakterologiczne nie są tutaj żadną niewiadomą, wszystko jest jasne i proste. Wiadomo, że Piotrek to mruk, a Marek lubi „gwiazdorzyć” i nikogo to nie dziwi. Tacy są w życiu, tacy są na próbach, tacy są na scenie. Gorzej, kiedy każdy pochodzi „z innej parafii", a na dodatek dzieli ich bariera wiekowa, edukacyjna czy materialna [sic!]. Na pewno trudniej wtedy o porozumienie i zespoły takie nazywa się zwykle projektami, z góry jakby zakładając, że to tylko na chwilę - nagramy coś i wracamy do swoich zajęć. Jakkolwiek by jednak nie było, zawsze łączy ich wszystkich specyficzny kod porozumiewania się czy żargon wytworzony na własny użytek. Tytuły piosenek, które zna publiczność, rzadko kiedy są tytułami, jakie wypowiadają na próbach członkowie zespołu. W tym celu używa się kryptonimów czyli tytułów roboczych, skrótowych, często żartobliwych. Własny język, sposób bycia i zachowania kodyfikuje grupę, przydając jej cech mafii, gangu lub zamkniętego kręgu dla wtajemniczonych co oczywiście wszystkim się bardzo podoba, ale z biegiem lat już wcale się nad tym faktem nie pochylając.

Mistycyzm wynikający $\mathrm{z}$ obsługi instrumentu również charakteryzuje zespół jako coś wyjątkowego, z pogranicza transcendencji. Wspólne granie to nie jest wspólny wyjazd na ryby. To coś więcej, coś uduchowionego i ezoterycznego. Dość powiedzieć, że muzycy z czasem upodabniają się do instrumentów, na których grają. Nie fizycznie, ale pod względem jakichś drgań czy fal, które po wydobyciu z instrumentu przenikają przez ich ciało basiści na ogół poważnieją, a wokaliści stają się ekstrawertykami. To jednak jest już temat do badań dla biologów, akustyków, psychofizjologów czy fizyków. W każdym razie, można wyobrazić sobie sytuację, w której muzycy pozbawieni werbalnego wyrażania uczuć i myśli wyrażają je za pomocą urządzeń zwanych instrumentami, a tak właśnie jest w przypadku wykonywania muzyki. John Lennon do muzyków sesyjnych zwracał się nie po imieniu, chociaż pewnie mógłby, bo z pewnością nie chodziło o wywyższanie się, ale per „basisto”, „perkusisto”. To także o czymś świadczy. 


\section{Coda}

Każdy zespół muzyczny jest hybrydą złożoną z osób zorientowanych w jakimś kierunku muzycznym. Muzyka, którą wykonują jest emanacją ich umiejętności, serca i wrażliwości, a więc konsekwencją tego wszystkiego i kompromisem między tym co chciałbym a co mogę. Niczym trybiki $\mathrm{w}$ jednej maszynie pracują na efekt w postaci piosenki, płyty, koncertu. Jeden zsynchronizowany organizm, a przecież tak wiele uczuć i indywidualnych możliwości twórczych. W grupach rockowych, w których ludzie chętnie i łatwo wyrażają swoje poglądy i są bardziej spontaniczni chociażby od symfoników nie jest łatwo zapanować nad chaosem. Przede wszystkim wynika on z mocy wzmacniaczy i perkusji i każdy muzyk zna te sytuacje, w których próbuje wyłożyć jakiś problem lub pomysł, a w tym czasie perkusista ćwiczy tzw. przejścia. Podobnie z gitarzystami wpadającymi w trans grania solówek. Utwór się kończy, ale nie solówka. Alice Cooper skonstatował kiedyś: „Gitarzystów trzeba trzymać krótko. Jak faceta nie przybastujesz w odpowiednim momencie, to solówkę może grać przez dwa lata”. Znane są też powszechnie przypadki jak trudno jest zebrać zespół razem, w tym samym miejscu i czasie, bo jeden ma za daleko na próby i trzeba go dowozić, a inny obrosły w rodzinę i życie zawodowe wciąż zmaga się z dylematem "mieć czy być”. Miles Davies powiedział kiedyś, że nie podaje ręki żonatym muzykom, bo tak jak Hitler poślubiony był Niemcom (według jego własnego mniemania), tak prawdziwego muzyka powinien znamionować mariaż z zespołem. Bycie muzykiem deformuje również psychikę człowieka, który po wielu latach grania doznaje zaburzeń obsesyjno-kompulsywnych w każdym ciekawym architektonicznie budynku, widząc znakomite miejsce na próby lub na zagranie koncertu i wciąż próbując rozwikłać zagadkę życia typu kto jest najlepszym basistą na Ziemi, a kto nagrał płytę wszechczasów.

Wszyscy muzycy, ci prawdziwi, a nie farbowani, to osobliwa rasa ludzi sfrustrowanych, głodnych sukcesu, wylęknionych, ale bluźnierczych, pośród których grupa muzyków rockowych stanowi najbardziej barwną, nieokiełznaną, enigmatyczną część zbioru wartą poświęcenia uwagi dla muzykologów, socjologów, psychologów, kulturoznawców, a nawet demografów i etnografów. To znakomity materiał do badań dla wszystkich humanistów i pasjonatów opiewających rodzaj ludzki w każdym jego działaniu, kreacji i emanacji.

\section{SUMMARY}

Sociological and psychological aspects of rock bands functioning

To say that a music band is a group of performers playing music together is to say nothing. Just like treasure hunters, where one knows the place, the other knows how 
to put formwork, and the third knows how to evaluate and distinguish minerals from precious stones, everyone in a musical group is different and necessary at the same time. It depends on their mutual relations, feelings, thoughts, words, and possibilities whether the treasure will be found, what victims will be incurred along the way, and whether their own ego will not exceed them. If all goes well, the golden music will remain with them for many years, and maybe even for generations. The only question is how not to sever ties? How to stay yourself? How not to get lost and how to find ...?

KEYWORDS: rock band, interpersonal relations, psychologism, social communication, personality, group 